\title{
THE EFFECT OF WASTEWATER DISPOSAL MANAGEMENT SYSTEM ON POPULATION HEALTH AT TIBAR VILLAGE, BAZARTETE SUB-DISTRICT, LIQUIÇA DISTRICT, TIMOR-LESTE
}

\author{
Levi Anatolia Soares Maia Exposto'), Marthen Robinson Pellokila²), \\ Pius Weraman 3 ) \\ 1)Faculty of Public Health, Universidade da Paz Timor Leste \\ 2,3)Masters Program in Public Health, Faculty of Public Health, \\ Nusa Cendana University
}

\begin{abstract}
Background: Poor waste disposal management is an important public health issue in developing countries including Timor Leste. Data from Posto Saúde Tibar, Liquiça sub-district, Liquiça district, Timor Leste showed that people who resided near final waste disposal were often affected by infectious diseases such as malaria acute respiratory infection, dengue, diarrhea, and skin disease. The purpose of this study was to determine the effect of wastewater disposal management system on population health at Tibar village, Bazartete sub-district, Liquiça district, Timor Leste.

Subjects and Method: This was a cross setional study conducted at SucoTibar, Bazartete sub-district, Liquiça district, Timor Leste. A sample of 34 families were selected for this study. The dependent variable was population health status. The independent variables were reduce, reuse, and recycle management system. Data were collected by questionnaire and observation sheet. The data were analyzed by multiple logistic regression.

Results: Absence of reduce $(\mathrm{OR}=0.33 ; 95 \% \mathrm{CI}=-1.53$ to $2.19 ; \mathrm{p}=0.004)$, reuse $(\mathrm{OR}=0.23 ; 95 \% \mathrm{CI}=-1.59$ to $2.13 ; \mathrm{p}=0.009)$, and recycle $(\mathrm{OR}=0.22$; 95\% $\mathrm{CI}=-1.64$ to $2.08 ; \mathrm{p}=0.020$ ) in the management system were associated with poorer population health status.

Conclusion: Absence of reduce, reuse, and recycle in the management system are associated with poorer population health status.
\end{abstract}

Keywords: reduce, reuse, recycle, management system, population health status

Correspondence: Levi Anatolia Soares Maia Exposto. Faculty of Public Health, Universidade da Paz Timor Leste. Email: levibebrete@yahoo.co.id. Mobile: +67077470374/ +6281353801455 